Article

\title{
Resolvin D1 and D2 Inhibit Transient Receptor Potential Vanilloid 1 and Ankyrin 1 Ion Channel Activation on Sensory Neurons via Lipid Raft Modification
}

\author{
Maja Payrits ${ }^{1,2}$, Ádám Horváth ${ }^{1,2, *}$, Tünde Biró-Sütô ${ }^{1,2}$, János Erostyák ${ }^{2,3}$, Géza Makkai ${ }^{2,3}$, \\ Éva Sághy 1,2,4 ${ }^{1}$, Krisztina Pohóczky 1,2,5®, Angéla Kecskés 1,2 , Miklós Kecskés 2,6, \\ János Szolcsányi ${ }^{1,+}$, Zsuzsanna Helyes ${ }^{1,2}$ and Éva Szóke ${ }^{1,2}$ \\ 1 Department of Pharmacology and Pharmacotherapy, Medical School, University of Pécs, Szigeti str. 12, \\ H-7624 Pécs, Hungary; payrits.maja@gmail.com (M.P.); tunde.suto@aok.pte.hu (T.B.-S.); \\ saghy.eva@med.semmelweis-univ.hu (É.S.); pohoczkykriszti@gmail.com (K.P.); \\ angela.kecskes@aok.pte.hu (A.K.); janos.szolcsanyi@aok.pte.hu (J.S.); zsuzsanna.helyes@aok.pte.hu (Z.H.); \\ eva.szoke@aok.pte.hu (É.S.) \\ 2 János Szentágothai Research Centre and Centre for Neuroscience, University of Pécs, Ifjúság str. 20, \\ H-7624 Pécs, Hungary; erostyak@fizika.ttk.pte.hu (J.E.); gezamakkai@gmail.com (G.M.); \\ kecskes.miklos@pte.hu (M.K.) \\ 3 Department of Experimental Physics, Faculty of Sciences, University of Pécs, Ifjúság str. 6, \\ H-7624 Pécs, Hungary \\ 4 Department of Pharmacology and Pharmacotherapy, Semmelweis University, Nagyvárad sq. 4, \\ H-1089 Budapest, Hungary \\ 5 Department of Pharmacology, Faculty of Pharmacy, University of Pécs, Szigeti str. 12, H-7624 Pécs, Hungary \\ 6 Institute of Physiology, Medical School, University of Pécs, Szigeti str. 12, H-7624 Pécs, Hungary \\ * Correspondence: horvatadam7@gmail.com \\ $\dagger$ Professor János Szolcsányi passed away during the course of this study. This paper is dedicated to \\ his memory.
}

Received: 29 April 2020; Accepted: 13 July 2020; Published: 16 July 2020

check for updates

\begin{abstract}
Transient Receptor Potential Vanilloid 1 and Ankyrin 1 (TRPV1, TRPA1) cation channels are expressed in nociceptive primary sensory neurons and regulate nociceptor and inflammatory functions. Resolvins are endogenous lipid mediators. Resolvin D1 (RvD1) is described as a selective inhibitor of TRPA1-related postoperative and inflammatory pain in mice acting on the G protein-coupled receptor DRV1/GPR32. Resolvin D2 (RvD2) is a very potent TRPV1 and TRPA1 inhibitor in DRG neurons, and decreases inflammatory pain in mice acting on the GPR18 receptor, via TRPV1/TRPA1-independent mechanisms. We provided evidence that resolvins inhibited neuropeptide release from the stimulated sensory nerve terminals by TRPV1 and TRPA1 activators capsaicin (CAPS) and allyl-isothiocyanate (AITC), respectively. We showed that RvD1 and RvD2 in nanomolar concentrations significantly decreased TRPV1 and TRPA1 activation on sensory neurons by fluorescent calcium imaging and inhibited the CAPS- and AITC-evoked ${ }^{45}$ Ca-uptake on TRPV1- and TRPA1-expressing CHO cells. Since $\mathrm{CHO}$ cells are unlikely to express resolvin receptors, resolvins are suggested to inhibit channel opening through surrounding lipid raft disruption. Here, we proved the ability of resolvins to alter the membrane polarity related to cholesterol composition by fluorescence spectroscopy. It is concluded that targeting lipid raft integrity can open novel peripheral analgesic opportunities by decreasing the activation of nociceptors.
\end{abstract}

Keywords: Resolvin D1; Resolvin D2; lipid rafts; transient receptor potential channel; sensory neuron; nerve terminal 


\section{Introduction}

The Transient Receptor Potential (TRP) Vanilloid 1 (TRPV1) and Ankyrin 1 (TRPA1) cation channels are co-localized on capsaicin (CAPS)-sensitive polymodal nociceptors, and mediate pain and neurogenic inflammation [1-4]. TRPV1 is gated by chemical irritants, such as CAPS, resiniferatoxin, several endogenous arachidonic- or other fatty-acid metabolites, protons $(\mathrm{pH}<6.0)$ and noxious heat $\left(>43^{\circ} \mathrm{C}\right)$ [5-10]. TRPA1 is gated by a variety of exogenous (such as allyl-isothiocyanate-AITC) and endogenous ligands (like primary amine metabolites, methylglyoxal [11-13]), cold $\left(<17^{\circ} \mathrm{C}\right)$, and mechanical stimuli [14-16]. Pro-inflammatory neuropeptides, such as calcitonin gene-related peptide (CGRP) and substance P are released from the activated TRPV1 and TRPA1-expressing sensory nerves and induce neurogenic inflammation (vasodilatation, plasma protein extravasation, and inflammatory cell stimulation) in the innervated area [17-19]. Neurogenic inflammation is an important pathophysiological component of diseases like asthma, rheumatoid arthritis, psoriasis, and inflammatory bowel diseases, and cannot be inhibited by any currently available drugs [20-22]. Furthermore, chronic neuropathic pain, in which the CAPS-sensitive nerves play an important role, is also an unmet medical need. The refore, inhibiting function of TRPV1 and TRPA1-expressing nociceptors is the focus of novel pharmacological approaches. Great effort has been dedicated to developing small-molecule TRPV1 and TRPA1 antagonists [2,3,23-28], but disrupting lipid rafts surrounding these TRP channels could also be a promising alternative way to inhibit receptor activation.

Lipid rafts are microdomains rich in cholesterol, sphingomyelins (SM), and gangliosides [29]. Cholesterol depletion by methyl $\beta$-cyclodextrin incubation resulted in impaired CAPS-evoked currents in dorsal root ganglion (DRG) neurons [30]. We proved that pharmacological depletion of SMs, cholesterol or gangliosides diminished TRPV1 and TRPA1 channel activation both on transfected cells and native sensory neurons [31,32]. A very recent study showed that lipid raft destabilization by methyl $\beta$-cyclodextrin also inhibits the responses of mouse TRPA1 to bacterial lipopolysaccharides and cold [33]. TRPA1 was described as being located in cholesterol-rich domains. The authors identified by in silico investigation cholesterol recognition amino acid consensus motifs in the TM2 and TM4 segments, which had a role in the inhibition of chemical activation of mouse TRPA1 by cholesterol depletors [34]. Cholesterol might influence TRP channel function by direct interaction with ion channels [34-36]. Sphingomyelinase hydrolyzes SM to phosphocholine and ceramide [37,38]. It did not only act on the sensory neuronal cell bodies, but also on the nerve terminals diminishing TRPV1 and TRPA1 activation-induced CGRP release, as a good indicator of channel inhibition [31]. The described changes of the plasma membrane composition related to lipid raft disruption could be investigated in a reliable manner by fluorescence spectroscopy, as have been reported earlier [31,32,39,40].

Identifying the endogenous inhibitors of TRPV1 and TRPA1 channels could open novel perspectives to understand their pharmacological opportunities. Resolvins are lipid mediators with pro-resolving and anti-inflammatory functions [41,42]. Resolvin D1 (RvD1) is derived from docosahexaenoic acid (Figure 1) [42] and is a potent inhibitor of inflammatory and postoperative pain, but its molecular mechanism of action is unclear [43-45]. RvD1 was described as a selective inhibitor of TRPA1 in DRG neurons [43]. Resolvin D2 (RvD2)—which is also a docosahexaenoic acid derivate (Figure 1) -is a regulator of leukocyte functions and controls sepsis [46]. RvD2 has been reported as a very potent TRPV1 and TRPA1 inhibitor in DRG neurons, which inhibited cation influx in nanomolar concentration ( $\mathrm{IC}_{50} 0.1 \mathrm{nM}$ for TRPV1 and $\mathrm{IC}_{50} 2.1 \mathrm{nM}$ for TRPA1) [47]. Peripheral and central administration of its low dose (0.01-10 ng) decreased acute, subacute, and persistent inflammatory pain in mouse models via TRPV1/TRPA1-independent mechanisms. This effect was suggested to be mediated by its specific $G$ protein-coupled receptor (GPR) [47], which was later identified by direct binding of ${ }^{3} \mathrm{H}$-labeled RvD2. It is called GPR18 when described on human leukocytes, including polymorphonuclear neutrophil cells, monocytes, and macrophages [48]. DRV1/GPR32 is the receptor for RvD1 identified in human leukocytes [49,50]. 


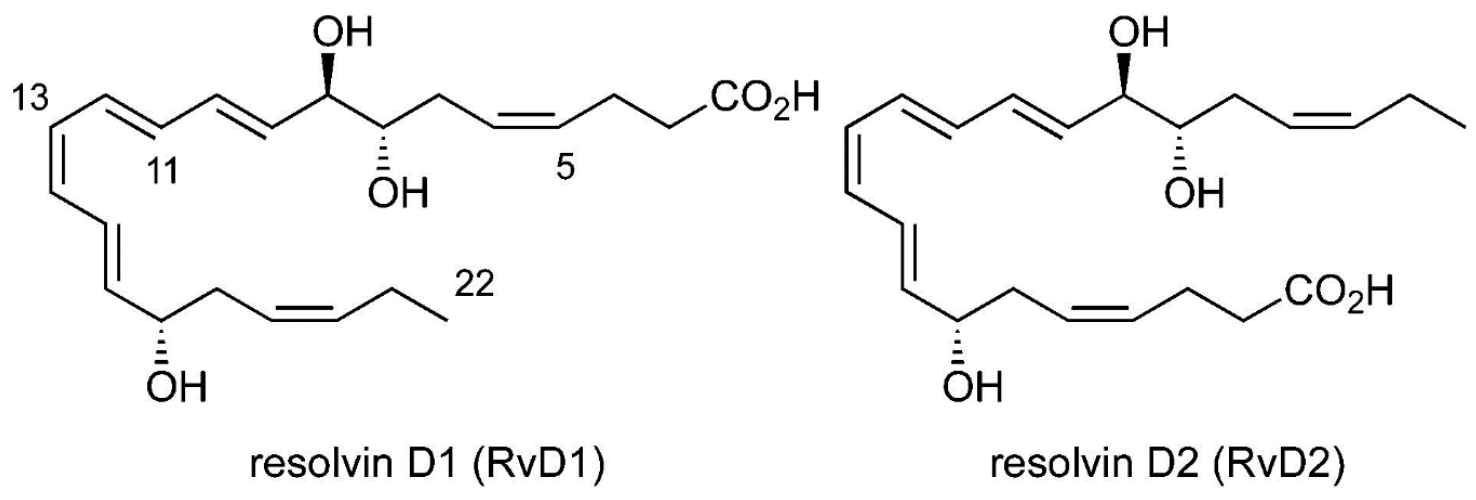

Figure 1. Structure of RvD1 and RvD2.

The present study investigated the effects of RvD1 and RvD2 on TRPV1 and TRPA1 receptor activation on trigeminal sensory neurons and peripheral sensory nerve endings and the involvement of lipid raft modification around these nocisensor ion channels in their mechanisms of action.

\section{Results}

2.1. RvD1 and RvD2 Inhibit TRPA1 and TRPV1 Receptor Activation-Mediated $\mathrm{Ca}^{2+}$-Influx in Cultured Trigeminal Ganglion (TG) Neurons

Firstly, the percentage of responding neurons with $\mathrm{Ca}^{2+}$-influx to $330 \mathrm{nM}$ CAPS and $200 \mu \mathrm{M}$ AITC was determined in control plates. In control plates, CAPS- and AITC-induced $\mathrm{Ca}^{2+}$-influx were detected in $57.1 \pm 8 \%$ ( 60 out of 104 , the $R$ value was $0.99 \pm 0.05$ ) and $25.6 \pm 5.6 \%$ (43 out of 170 , the $R$ value was $0.98 \pm 0.07$ ) of the cells, respectively. RvD1 treatment in $10 \mathrm{nM}$ significantly decreased not just the proportion of cells responding to CAPS and AITC resulting in $42.1 \pm 6.5 \%$ (40 out of 94) and 7 $\pm 3.2 \%$ ( 8 out of 91 ) responsive cells, respectively, but also the $R$ values, resulting in $R=0.73 \pm 0.07$ and $0.46 \pm 0.06$, respectively. After $2 \mathrm{nM}$ RvD1 incubation, the percent of responsive cells to CAPS was unaffected ( $59.5 \pm 7 \%$ (63 out of 106)), while it diminished the AITC-evoked responses to $14.3 \pm 3.4 \%$ (12 out of 84 ) (Figure 2A-D).

Significant decreases in the percent of CAPS- and AITC-sensitive cells were observed after 2 and $10 \mathrm{nM}$ RvD2 incubation, resulting in $44.8 \pm 5.8 \%$ (48 out of 108 ) and $17 \pm 3.3 \%$ (18 out of 102 ) in the case of CAPS and $18.1 \pm 3.7 \%$ (20 out of 108 ) and $11 \pm 4.1 \%$ (9 out of 89 ) responsive cells in the case of AITC, respectively (Figure 2E-H). The related $R$ values in the case of CAPS have been decreased also to $0.71 \pm 0.05$ and $0.35 \pm 0.05$ after 2 and $10 \mathrm{nM} \mathrm{RvD2}$ incubation, respectively, and similar decreases were observed in the case of AITC, resulting in $0.66 \pm 0.05$ and $0.29 \pm 0.02 R$ values, respectively (Figure 2E-H). Original recordings of CAPS- and AITC-induced $\mathrm{Ca}^{2+}$-influx in TG neurons are presented in Figure 3.

The overnight pertussis toxin (PTX) treatment did not prevent the inhibitory effect of the higher doses of RvD1 and RvD2 on TRPV1 and TRPA1 receptor activation (Figure 4A,B). Neither RvD1 nor RvD2 affected the $50 \mathrm{mM} \mathrm{KCl-evoked} \mathrm{voltage-gated} \mathrm{Ca}^{2+}$ channel activation (Figure 4C). 

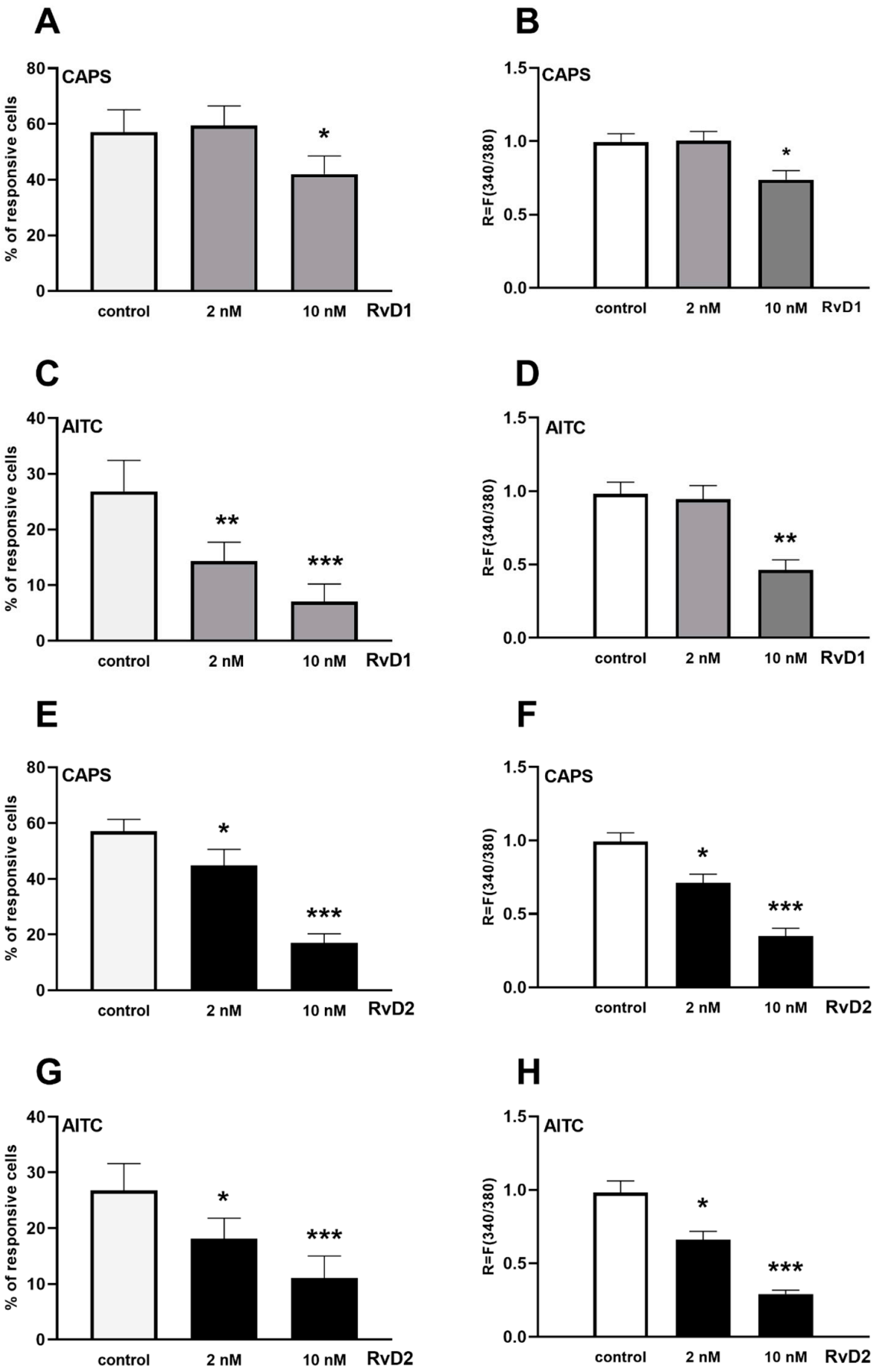

Figure 2. Effect of RvD1 and RvD2 on TRPV1 and TRPA1 receptor activation on cultured trigeminal ganglion sensory neurons. (A,E): The percentage of responsive cells to capsaicin (CAPS) is presented after (A): RvD1 ( 2 and $10 \mathrm{nM}, n=94-106$ cells per group) and (E): RvD2 ( 2 and $10 \mathrm{nM}, n=102-108$ cells per group) administration. (B,F): Change in the fluorescence ratio $(R=F 340 / F 380)$ after TRPV1 receptor activation in CAPS-sensitive cells is presented after (B): RvD1 and (E): RvD2 treatment. $(\mathrm{C}, \mathrm{G})$ : The percentage of responsive cells to allyl-isothiocyanate (AITC) is presented after (C): RvD1 ( 2 and $10 \mathrm{nM}, n=84-170$ cells per group) and (G): RvD2 (2 and $10 \mathrm{nM}, n=89-170$ cells per group) administration. $(\mathbf{D}, \mathbf{H})$ : Change in the fluorescence ratio $(R=F 340 / F 380)$ after TRPA1 receptor activation in AITC-sensitive cells is presented after (D): RvD1 and (H): RvD2 treatment. $\mathrm{Ca}^{2+}$-responses are presented in $\%$ of total number of examined neurons. $\left({ }^{*} p<0.05,{ }^{* *} p<0.01,{ }^{* * *} p<0.001\right.$ (control vs. treated, one-way ANOVA, Dunnett's post hoc test). 
CAPS

A
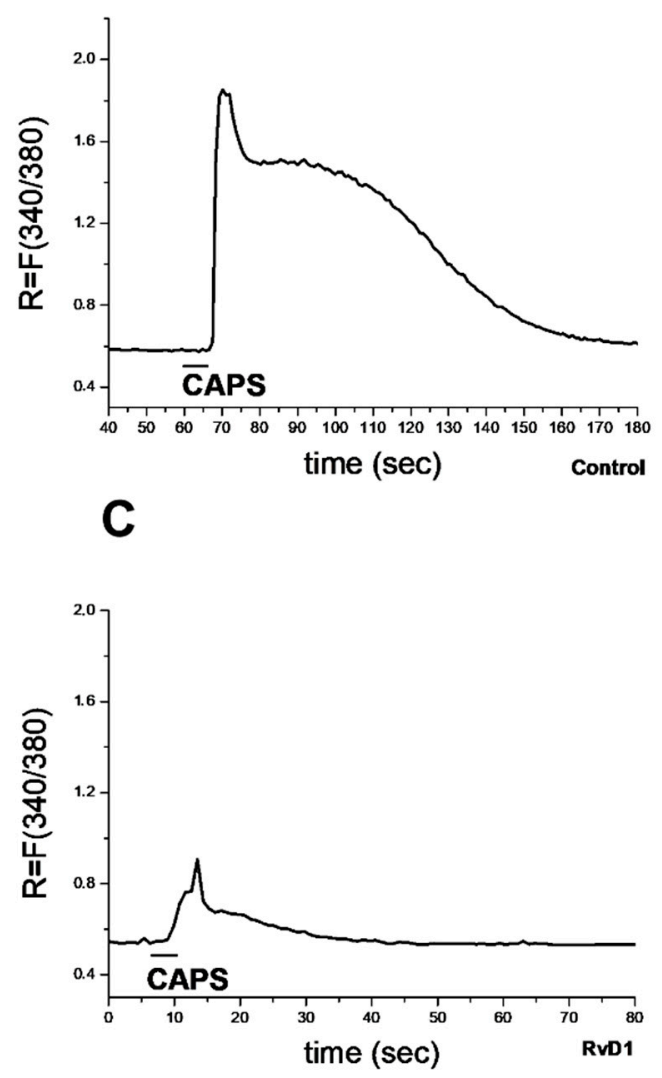

E

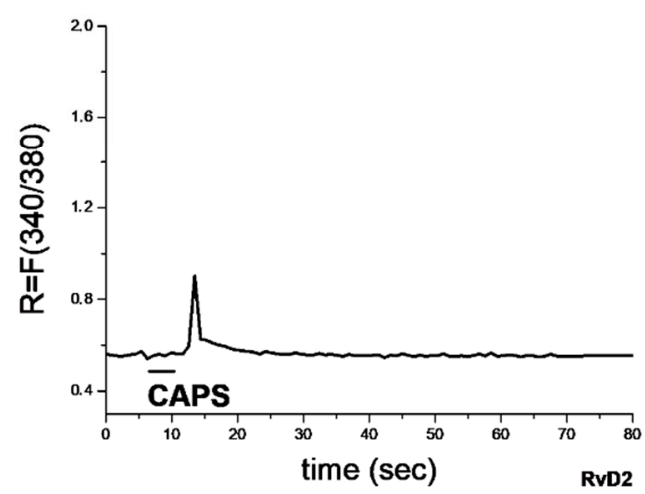

AITC

B

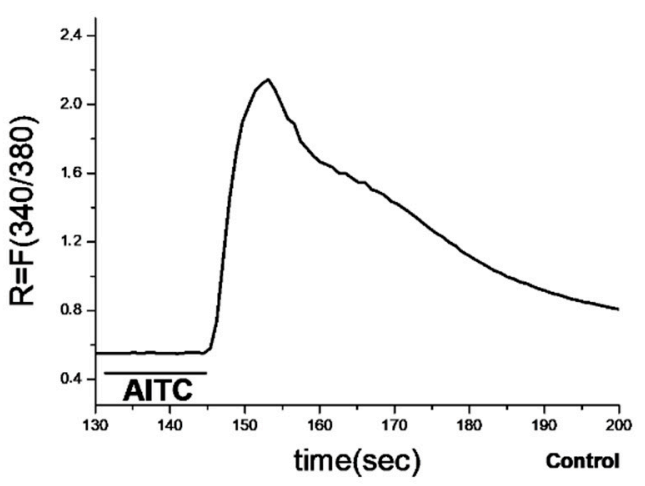

D

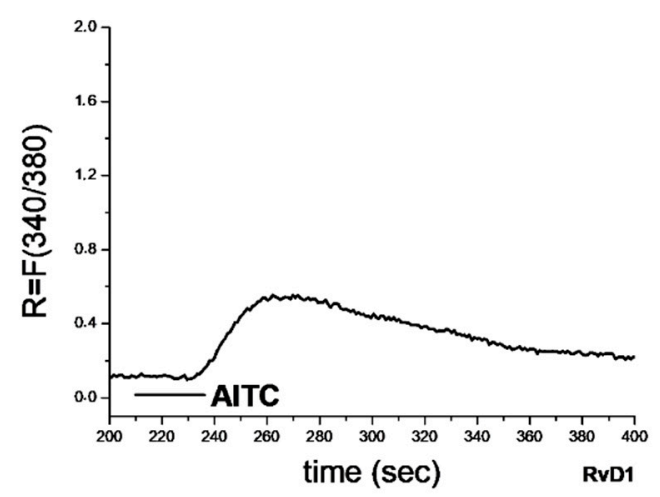

F

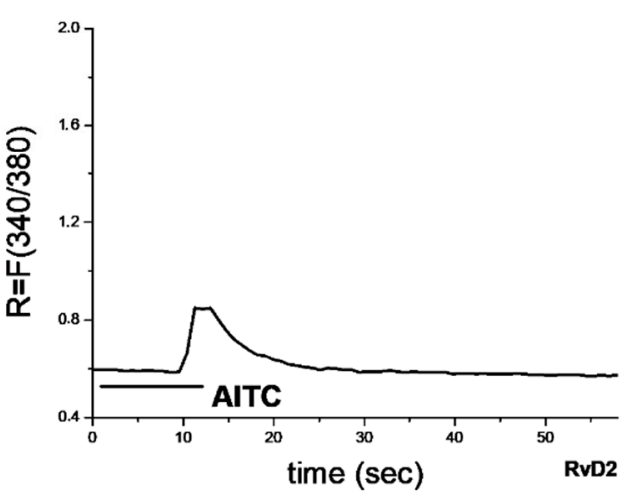

Figure 3. Effect of RvD1 and RvD2 on TRPV1 and TRPA1 receptor activation on cultured TG sensory neurons. Increases in $R=340 / 380$ fluorescence in fura-2 loaded cultured TG neurons. Original recording from CAPS (A,C,E)- and AITC (B,D,F)-sensitive neurons on control (A,B), RvD1-treated (C,D) or RvD2-treated (E,F) plates. 


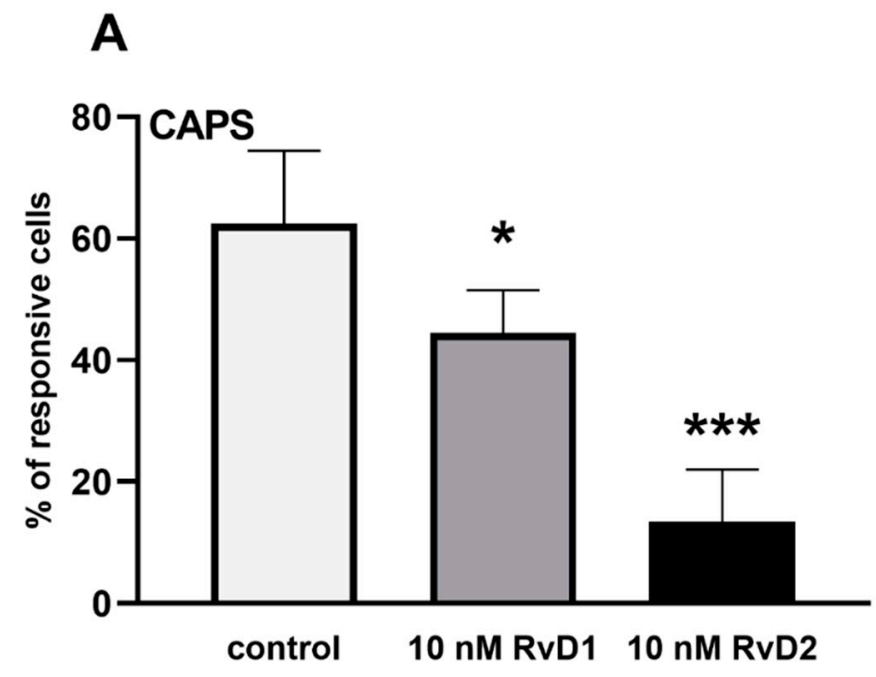

B
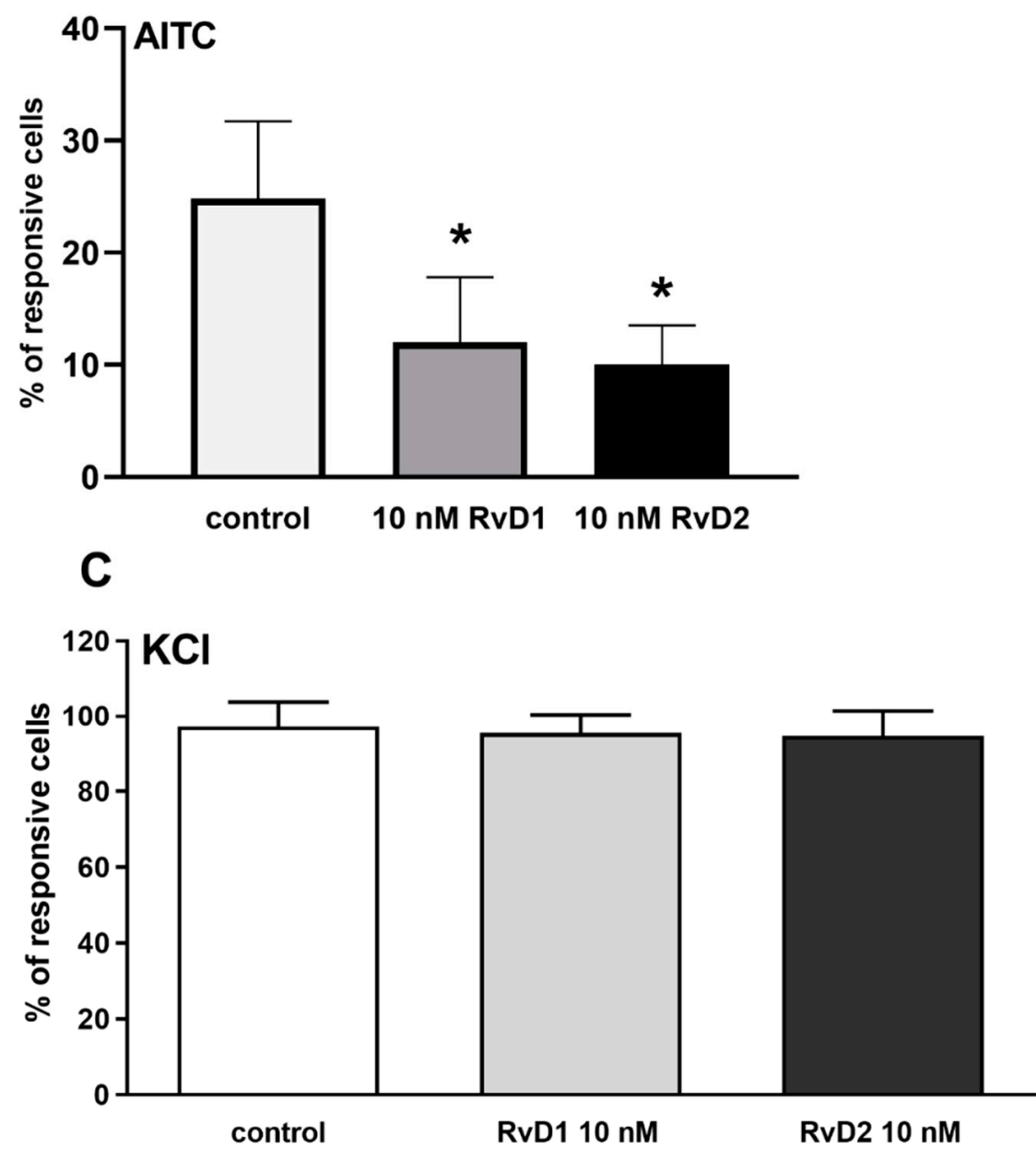

Figure 4. Effect of RvD1 and RvD2 on TRPV1 and TRPA1 receptor activation on cultured TG sensory neurons after PTX treatment and on $\mathrm{KCl}$-evoked voltage gated $\mathrm{Ca}^{2+}$ channel activation. (A): The percentage of responsive cells to CAPS is presented after RvD1 or RvD2 (both of them $10 \mathrm{nM}$ ) administration. (B): The percentage of responsive cells to AITC is presented after RvD1 or RvD2 (both of them $10 \mathrm{nM}$ ) administration. (C): The percentage of responsive cells to $\mathrm{KCl}$ is presented after RvD1 or RvD2 (both of them $10 \mathrm{nM}$ ) administration. $\left({ }^{*} p<0.05,{ }^{* * *} p<0.001\right.$ (control vs. treated, one-way ANOVA, Dunnett's post hoc test). 


\subsection{RvD1 and RvD2 Decrease TRPV1 and TRPA1 Activation-Evoked CGRP Release from Peripheral Sensory Nerves}

TRPV1 activation by $100 \mathrm{nM}$ CAPS induced $1.2 \pm 0.19 \mathrm{fmol} / \mathrm{mg}$ CGRP release from the sensory nerves of the rat trachea. TRPA 1 activation by $100 \mu \mathrm{M}$ AITC evoked $0.57 \pm 0.1 \mathrm{fmol} / \mathrm{mg}$ CGRP outflow, which is approximately half of the effect of CAPS. RvD1 significantly decreased the CAPS-evoked CGRP release in $100 \mathrm{nM}$ concentration to $0.8 \pm 0.09 \mathrm{fmol} / \mathrm{mg}$ (Figure 5A) and the AITC-induced peptide outflow in 50 and $100 \mathrm{nM}$ concentration to $0.32 \pm 0.09 \mathrm{fmol} / \mathrm{mg}$ and $0.27 \pm 0.1 \mathrm{fmol} / \mathrm{mg}$ (Figure 5B). RvD2 was able to diminish the CGRP release in a ten-fold lower concentration. It decreased significantly the CAPS- and AITC-evoked CGRP release in $5 \mathrm{nM}$ concentration to $0.89 \pm 0.15$ and $0.29 \pm 0.11 \mathrm{fmol} / \mathrm{mg}$, respectively, and in $10 \mathrm{nM}$ concentration to $0.67 \pm 0.19$ and $0.22 \pm 0.02 \mathrm{fmol} / \mathrm{mg}$, respectively (Figure 5C,D). RvD1 and RvD2 did not influence the basal, non-stimulated peptide outflow (data not shown) and $\mathrm{KCl}$-evoked CGRP release (Figure 5E).

A

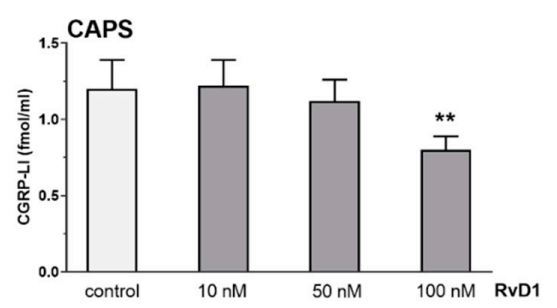

C

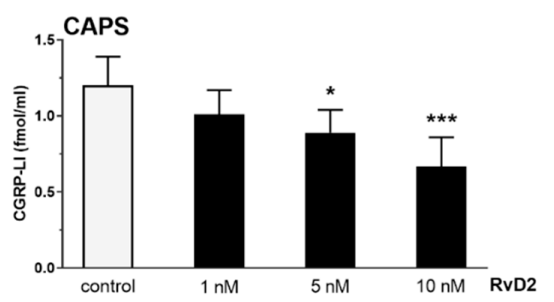

B

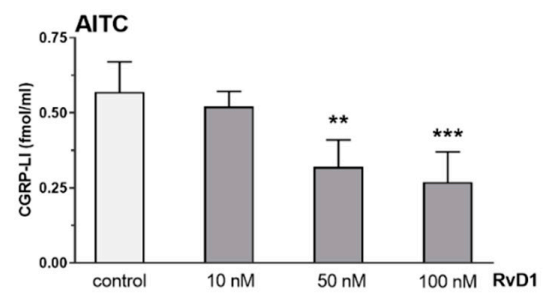

D

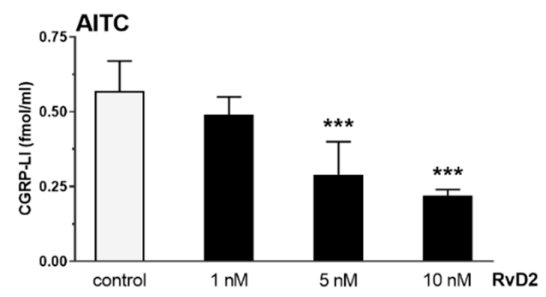

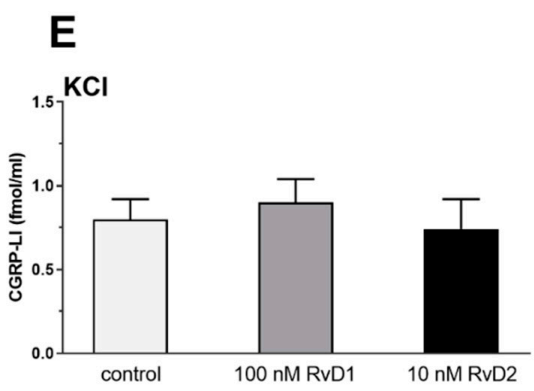

Figure 5. Effect of RvD1 and RvD2 on TRPV1 and TRPA1 receptor activation on peripheral nerve terminals. (A,B): Effect of 10, 50, and $100 \mathrm{nM} \mathrm{RvD1}$ on $100 \mathrm{nMCAPS}$-evoked (A) or $100 \mu \mathrm{M}$ AITC-evoked (B) CGRP release. (C,D): Effect of 1, 5, and $10 \mathrm{nM}$ RvD2 on $100 \mathrm{nM}$ CAPS-evoked (C) or $100 \mu \mathrm{M}$ AITC-evoked (D) CGRP release. (E): Effect of $100 \mathrm{nM}$ RvD1 and $10 \mathrm{nM}$ RvD2 on $50 \mathrm{mM}$ KCl-evoked CGRP release. Each column represents the mean + SEM of values of 6-8 experiments. As this method is a radioimmunoassay, CGRP release is represented as CGRP-like immunoreactivity (CGRP-LI) (* $p<0.05,{ }^{* *} p<0.01,{ }^{* * *} p<0.001$ control vs. treated, one-way ANOVA, Dunnett's post hoc test). 
2.3. RvD1 and RvD2 Inhibit the CAPS- and AITC-Evoked ${ }^{45}$ Ca-Uptake on Chinese Hamster Ovary (CHO) Cells Expressing the Cloned TRPV1 and TRPA1 Receptor

A significant decrease in CAPS-evoked ${ }^{45}$ Ca-accumulation was observed when CAPS was co-administered with $10 \mathrm{nM}$ RvD1 on TRPV1-expressing CHO cells. The percent value of ${ }^{45} \mathrm{Ca}$-uptake relative to the untreated control $(100 \%)$ was $68.33 \pm 18.14 \%$ after RvD1 treatment (Figure $6 \mathrm{~A}$ ). The highest concentration of RvD2 was able decreased the CAPS-evoked ${ }^{45}$ Ca-uptake, and the percent value was $46 \pm 14.4 \%$ relative to the untreated control (Figure $6 \mathrm{C}$ ).

A

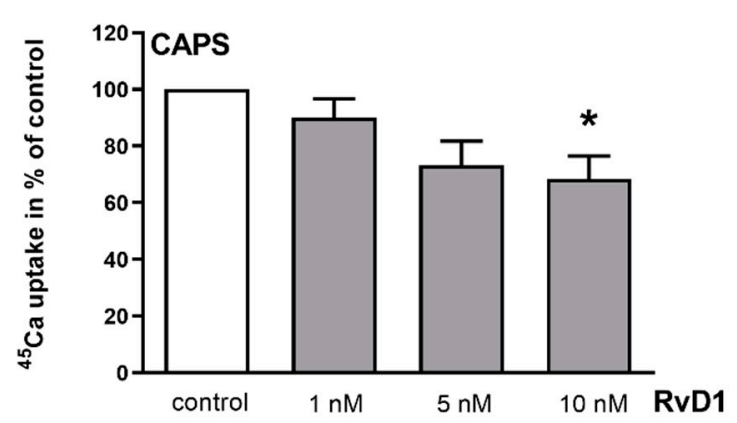

C

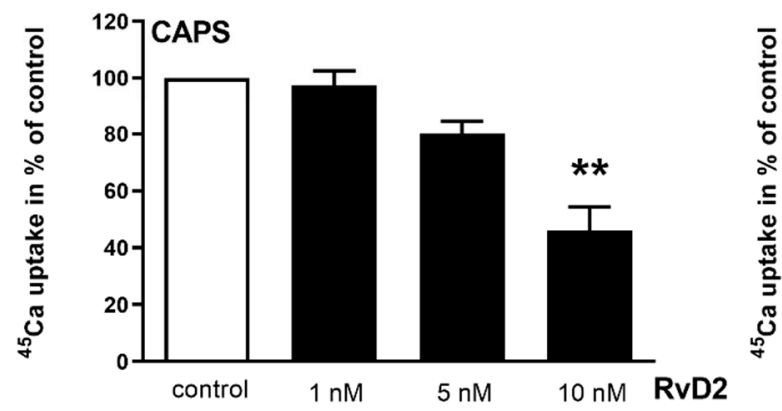

B

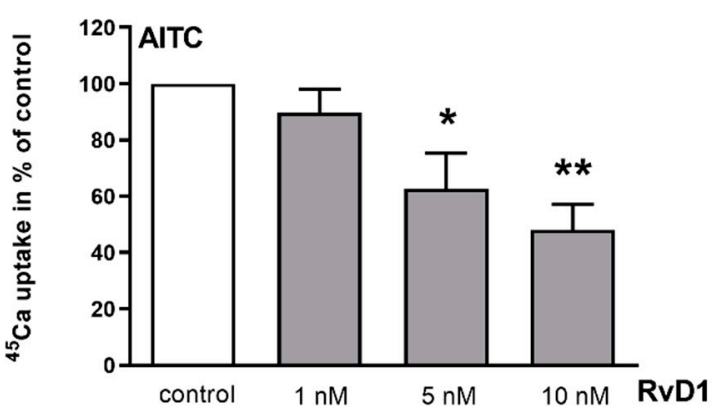

D

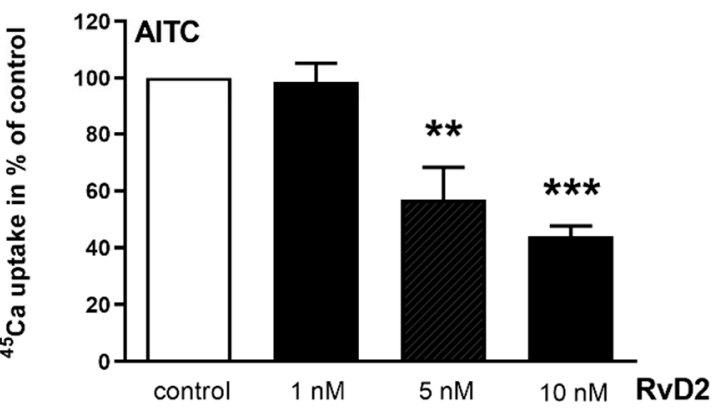

Figure 6. Effect of RvD1 and RvD2 on CAPS- and AITC-evoked ${ }^{45}$ Ca-uptake on CHO cells expressing the cloned TRPV1 and TRPA1 receptor. (A,B): Effect of RvD1 on TRPV1-expressing (A) and TRPA1-expressing (B) CHO cells in radioactive ${ }^{45}$ Ca-uptake experiments after CAPS (100 nM) and AITC $(100 \mu \mathrm{M})$ administration. (C,D): Effect of RvD2 on TRPV1-expressing (C) and TRPA1-expressing (D) $\mathrm{CHO}$ cells in radioactive ${ }^{45}$ Ca-uptake experiments after CAPS (100 nM) and AITC $(100 \mu \mathrm{M})$ administration. ${ }^{45} \mathrm{Ca}$-accumulations are presented in $\%$ of control (non-treated). Each column represents the mean + SEM of values of nine experiments. $\left({ }^{*} p<0.05,{ }^{* *} p<0.01,{ }^{* * *} p<0.001\right.$ (control vs. treated, one-way ANOVA, Dunnett's post hoc test).

Both 5 and $10 \mathrm{nM}$ RvD1 and RvD2 significantly diminished the AITC-induced ${ }^{45}$ Ca-uptake relative to the control, and these values were $62.66 \pm 21.2 \%$ and $48 \pm 14.9 \%$ in the case of RvD1 and $57 \pm 19 \%$ and $44 \pm 6.2 \%$ in the case of RvD2, respectively (Figure $6 \mathrm{~B}, \mathrm{D}$ ).

\subsection{RvD1 and RvD2 Change the Membrane Polarity on CHO Cells}

To investigate the effect of RvD1 and RvD2 on lipid raft integrity, fluorescent spectroscopy measurements with 6-dodecanoyl-N,N-dimethyl-2-naphthylamine (Laurdan)—a membrane polarity selective probe-were performed on $\mathrm{CHO}$ cells.

There is no spectral shift, broadening or any change in the shape of the spectra, but serious intensity change can be seen, which means that the micro-environment of Laurdan is changed by both RvD1 and RvD2 (Figure 7A,B). 

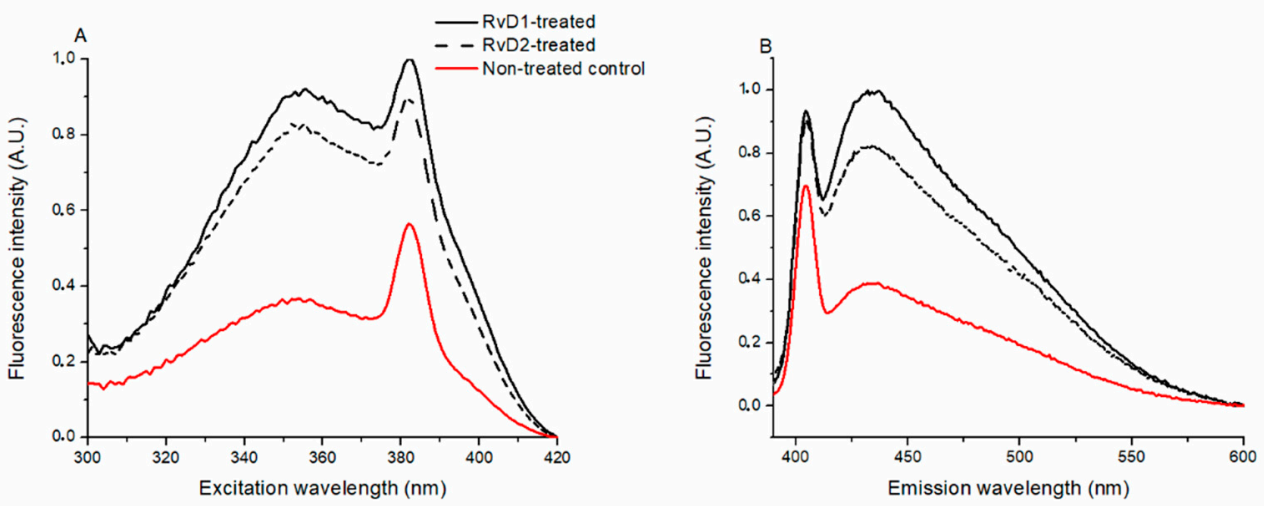

Figure 7. Effect of RvD1 and RvD2 on Laurdan excitation (A) and emission (B) spectra on CHO cells. Excitation wavelength: $440 \mathrm{nM}$, emission wavelength: $355 \mathrm{nM}$. Solid (black) or dashed and solid (red) curves represent the RvD1 or RvD2 and non-treated control samples, respectively.

Excitation-emission matrices also show that the RvD1- and RvD2-treated samples (cultured CHO cells) (Figure 8A,B) have higher fluorescence intensity than the non-treated control sample (Figure 8C) on the entire spectral region of fluorescence of Laurdan. The anisotropy values are practically the same on the whole spectral range in the case of RvD1-, RvD2-treated, and non-treated control samples (Figure 8D).
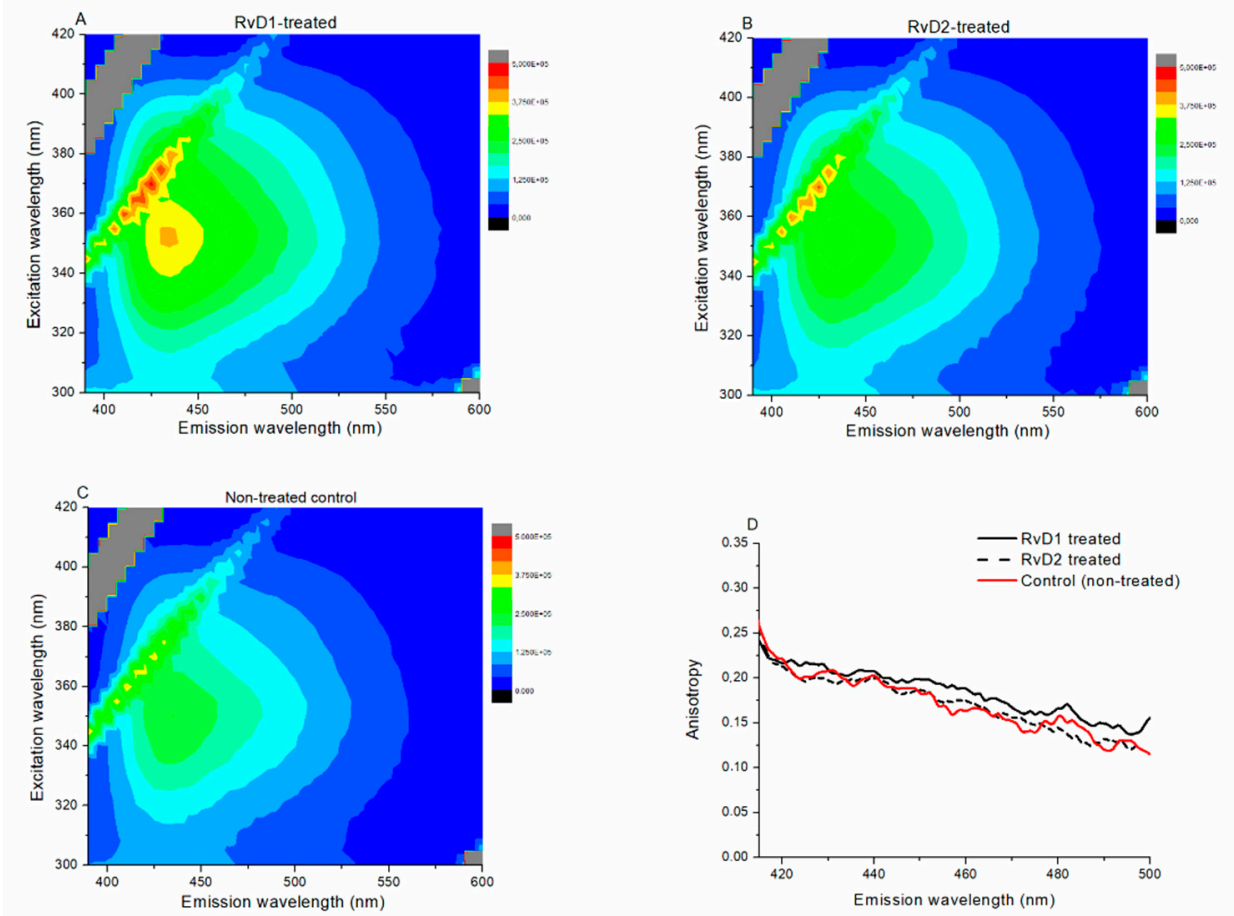

Figure 8. Excitation-emission matrices of RvD1-treated (A), RvD2-treated (B), and non-treated control (C) samples. (D): Emission anisotropy spectra of RvD1 (solid black), RvD2 (dashed black), and non-treated control (solid red) samples.

\section{Discussion}

This is the first paper providing evidence that resolvins inhibit the activation of TRPV1 and TRPA1 ion channels on sensory nerve terminals besides the cell bodies via modifying the membrane composition and lipid rafts. Our results on TG neurons confirm that RvD2 is a potent inhibitor of the TRPV1 and TRPA1 receptors in nanomolar concentrations. In contrast to the earlier studies conducted 
on DRG neurons [47], we showed that RvD1 treatment in $10 \mathrm{nM}$ concentration significantly decreased both the magnitude of $\mathrm{Ca}^{2+}$-influx in TG neurons and the proportion of cells responding to TRPV1 activation in addition to TRPA1 stimulation. Similarly to the literature data [47], RvD2 had more pronounced inhibitory action on both TRPV1 and TRPA1 channels. PTX pretreatment did not affect the inhibitory effect of the $10 \mathrm{nM}$ doses of RvD1 and RvD2 on TRPV1 and TRPA1 ion channel activity in cultured TG neurons. Previous studies described that pretreatment of DRG cultures with PTX blocked inhibitory effects of lower concentration $(1 \mathrm{nM})$ of RvE1 on capsaicin-induced TRPV1 activation [51]. Another study described that PTX treatment also blocked the effect of nanomolar doses of RvD1 and RvD2 on TRPV1 and TRPA1 channel activation [47]. Our results with higher doses of resolvins suggests another G-protein-independent way of inhibition. $\mathrm{KCl}$-evoked voltage-gated $\mathrm{Ca}^{2+}$ channel activation remained unaltered after RvD1 or RvD2 treatment. The trachea is a good model system to examine the activation of sensory nerve terminals because the nerves are close to the surface and they can be easily stimulated [52,53]. RvD2 concentrations ( 5 and $10 \mathrm{nM})$ to reduce TRPV1 and TRPA1 activation on the sensory nerve terminals shown by the decreased CGRP release were similar to that needed for the inhibitory action on the isolated cell bodies. However, 10-fold higher concentrations of RvD1 had to be used to exert similar inhibitory actions to RvD2 on the nerve endings, which might be explained by its weaker penetration abilities into deeper tissue layers. Neither RvD1 nor RvD2 decreased the $50 \mathrm{mM}$ KCl-induced CGRP release.

RvD1 was originally characterized as a selective TRPA1 inhibitor in DRG neurons and human embryonic kidney cells in nanomolar concentration by patch clamp and calcium imaging studies [43,47]. However, RvD1 inhibited fluorescent $\mathrm{Ca}^{2+}$-influx into TG sensory neurons in our experimental system in response to both TRPV1 and TRPA1 activations, although higher concentration (10 nM) was needed for TRPV1 inhibition. In contrast to RvD1, RvD2 was described as a potent inhibitor of both TRPV1 and TRPA1 in DRG cells, with a 20-fold higher potency for TRPV1 (IC 50 : 0.1 and $2.1 \mathrm{nM}$ for TRPV1 and TRPA1, respectively). Peripheral and central administration of RvD2 in very low doses (0.01-10 ng) attenuated Complete Freund's adjuvant-induced inflammatory pain-related spinal long-term potentiation in mice in a TRPV1/TRPA1-independent manner [47]. It has been suggested that pro-resolving mediators such as RvD1 exert activity via specific GPRs, similarly to lipoxin A4 and Resolvin E1 [42]. The RvD1 receptor named DRV1/GPR32 was identified via library screening and with ${ }^{3} \mathrm{H}$-labeled ligand binding [49]. RvD1 was reported as an endogenous inhibitor for the TRPA1, TRPV3, and TRPV4 channels by $\mathrm{Ca}^{2+}$ imaging experiments on transfected HEK293T cells and whole cell patch-clamp and $\mathrm{Ca}^{2+}$ imaging experiments on mouse DRG sensory neurons. RvD1 suppressed the three TRP channels-mediated nociceptive behaviors in mice [43]. The naturally occurring pro-resolving lipid 17R-RvD1 is a specific inhibitor of TRPV3. The results of $\mathrm{Ca}^{2+}$ imaging and whole cell electrophysiology experiments on receptor-expressing HEK cells, sensory neurons, keratinocytes, and behavioral studies suggest that 17R-RvD1 has an acute analgesic effect on TRPV3 ion channels [54]. Intrathecal RvD1 administration prevented postoperative hyperalgesia and mechanical allodynia in a skin-muscle retraction rat model [45]. Intrathecal RvD1 treatment prevented mechanical allodynia in a chronic pancreatitis model [55]. Feng and co-workers suggest that RvD1 attenuated the phosphorylation of nMDA receptor subunits and down-regulated the expression of inflammatory cytokines in the spinal dorsal horn [55]. Pretreatment with the selective G $\alpha$ i-coupled GPR inhibitor pertussis toxin as well as the G-protein blocker guanosine-5'-( $\beta$-thio)-diphosphate sodium salt prevented the RvD2-induced inhibition of TRPV1- and TRPA1-mediated responses on DRG sensory neurons, providing evidence for GPR-mediated actions [47]. Later, GPR18 was identified as the receptor for RvD2 by ${ }^{3} \mathrm{H}-$ labeled ligand binding and receptor knockout mice. GPR18 expression was describe on human leukocytes, including polymorphonuclear neutrophil cells, monocytes, and macrophages [48].

On TRPV1-expressing CHO cells, RvD1 and RvD2 induced significant decrease in CAPS-evoked ${ }^{45}$ Ca-accumulation only at $10 \mathrm{nM}$ concentrations. However, both 5 and $10 \mathrm{nM}$ RvD1 and RvD2 significantly and concentration dependently decreased the AITC-induced ${ }^{45}$ Ca-uptake on TRPA1-expressing $\mathrm{CHO}$ cells. Since these cells are unlikely to express the resolvin receptors, RvD1 
and RvD2 are suggested to inhibit TRP channel activation through surrounding lipid raft disruption. The results that PTX pretreatment did not affect the inhibitory effect of the higher $10 \mathrm{nM}$ doses of RvD1 and RvD2 on TRPV1 and TRPA1 ion channel activation in cultured TG neurons also suggest G-protein-independent way of inhibition. $\mathrm{KCl}$-induced $\mathrm{Ca}^{2+}$-influx in TG cells and CGRP release from sensory nerve endings remained unaltered after RvD1 or RvD2 treatment. Our previous results confirmed that lipid raft disruption did not alter $\mathrm{KCl}$-evoked voltage-gated $\mathrm{Ca}^{2+}$ channel activation [31]. Here, we provide the first direct evidence by fluorescence spectroscopy for the ability of RvD1 and $\mathrm{RvD} 2$ to induce transition from liquid-ordered to liquid-disordered phase in the plasma membrane, indicating cholesterol depletion [30-32] and leading to lipid rafts disintegration. High intensity change, but no anisotropy, was observed after both resolvin treatments, indicating less non-radiative processes of Laurdan, less interactions with its micro-environment, and rotational motion restricted to the non-treated control level within the membrane [31,32].

We showed here a dual inhibitory effect of RvD1 and RvD2 on TRPV1 and TRPA1 ion channels via surrounding lipid raft decomposition in the membrane. The se results suggest that targeting lipid raft integrity can open novel peripheral analgesic opportunities by decreasing the activation potentials of nociceptors.

\section{Materials and Methods}

\subsection{Primary Cultures of TG Neurons}

Cells of TG of 1-4 days old Wistar rat pups (6 pups/experiment) were cultured. The ganglia were cut and placed into ice cold phosphate-buffered saline (PBS), incubated for $35 \mathrm{~min}$ at $37^{\circ} \mathrm{C}$ in PBS containing collagenase (Type XI, $1 \mathrm{mg} / \mathrm{mL}$ ), and then, in PBS with deoxyribonuclease I (1000 units $/ \mathrm{mL}$ ) for $8 \mathrm{~min}$. The ganglia were then dissociated by trituration. Cell cultures were plated on poly-D-lysin-coated glass coverslips and grown in a nutrient-supplemented medium that contained $180 \mathrm{~mL}$ Dulbecco's-Modified Eagle Medium (DMEM), $20 \mathrm{~mL}$ horse serum, $20 \mathrm{~mL}$ bovine albumin, $2 \mathrm{~mL}$ insulin-transferrin-selenium-S, $3.2 \mathrm{~mL}$ putrescin dihydrochloride $(100 \mu \mathrm{g} / \mathrm{mL}), 20 \mu \mathrm{L}$ triiodo-thyronine $(0.2 \mathrm{mg} / \mathrm{mL}), 1.24 \mathrm{~mL}$ progesterone $(0.5 \mathrm{mg} / \mathrm{mL}), 100 \mu \mathrm{L}$ penicillin, and $100 \mu \mathrm{L}$ streptomycin. Cultures were maintained at $37^{\circ} \mathrm{C}$ in a humidified atmosphere with $5 \% \mathrm{CO}_{2}$, and nerve growth factor (NGF, $200 \mathrm{ng} / \mathrm{mL}$ ) was added every second day, as described earlier [56].

\subsection{Ratiometric Technique of Intracellular Free Calcium Concentration $\left(\left[\mathrm{Ca}^{2+}\right]_{i}\right)$ Measurement with the Fluorescent Indicator Fura-2-Acetoxymethyl Ester (Fura-2-AM)}

One to three-days-old cell cultures were stained for $30 \mathrm{~min}$ at $37{ }^{\circ} \mathrm{C}$ with $1 \mu \mathrm{M}$ of fluorescent $\mathrm{Ca}^{2+}$ indicator dye-fura-2-AM (Molecular Probes)—-then, washed in extracellular solution (ECS). ECS was gravity fed to the cells using a triple outlet tube and test solutions arrived at the outlet via separate tubes. We could control the rapid changing of solutions by a fast step perfusion system (VC-77SP, Warner Instrument Corporation, Harvard Apparatus GmbH, Freiburg, Germany). Calcium transients of TG neurons to CAPS (stimulation was $10 \mathrm{~s}$ ) and AITC (stimulation was $15 \mathrm{~s}$ ) were examined with microfluorimetry, as described elsewhere [56]. Fluorescence images were taken with an Olympus LUMPLAN FI/x20 0.5 W water immersion objective and a digital camera (CCD, SensiCam PCO, Kelheim, Germany), connected to a computer. Cells were illuminated alternately with 340 and $380 \mathrm{nM}$ light generated by a monochromator (Polychrome II., Till Photonics, Kaufbeuren, Germany) under the control of Axon Imaging Workbench 2.1 (AIW, Axon Instruments, CA). We measured the emitted light $>510 \mathrm{nM}$. The $R=\frac{F 340}{F 380}$ was monitored (rate $1 \mathrm{~Hz}$ ) continuously for up to $2 \mathrm{~min}$, while a few sample images were also recorded. The $R$ values were generated by AIW 2.1 software, then, processed by the Origin software version 8.0 (Originlab Corp., Northampton, MA, USA). Baseline was adjusted to $R=0$, and the peak magnitude of ratiometric responses was calculated.

Neurons were incubated with $1 \mu \mathrm{g} / \mathrm{mL}$ PTX overnight, 2 and $10 \mathrm{nM} \mathrm{RvD1}$ and RvD2 for $60 \mathrm{~min}$, respectively, at $37^{\circ} \mathrm{C}$ in a humidified atmosphere with $5 \% \mathrm{CO}_{2}$, or were untreated controls. 
To investigate the voltage-gated ion channel alteration, $50 \mathrm{mM} \mathrm{KCl}$ was applied after RvD1 and RvD2 incubation.

\subsection{Measurement of TRPV1/TRPA1 Activation-Induced CGRP Release from Sensory Nerve Endings of the Isolated Rat Trachea}

This method has been described in detail elsewhere [52,53]. In brief, rats (age of 30-40 weeks; in total, 196 animals) were exsanguinated in deep anesthesia (sodium thiobarbital $50 \mathrm{mg} / \mathrm{kg}$ intraperitoneal), then, tracheae were removed, cleaned of fat and adhering connective tissues, and placed into an organ bath to achieve sufficient amounts of peptide release and perfused $(1 \mathrm{~mL} / \mathrm{min})$ with $\mathrm{pH}$ 7.2 controlled oxygenated Krebs solution for $60 \mathrm{~min}$ (equilibration period) at $37^{\circ} \mathrm{C}$. The $\mathrm{n}$, they were incubated in the presence of $\operatorname{RvD} 1(10,50$, and $100 \mathrm{nM})$ or $\operatorname{RvD2}(1,5$, and $10 \mathrm{nM})$ for $60 \mathrm{~min}$ or left untreated for control. The trachea is an excellent model to investigate the activation of peripheral nerve terminals. The se nerve endings are close to the surface and they can be easily stimulated by different agonists. After discontinuation of the flow, the solution was changed three times for $8 \mathrm{~min}$ to produce pre-stimulated, stimulated and post-stimulated fractions. Chemical activation was performed in the second $8 \mathrm{~min}$ period, with the selective TRPV1 agonist CAPS $(100 \mathrm{nM})$ or the TRPA1 agonist AITC $(100 \mu \mathrm{M})$ or $\mathrm{KCl}(50 \mathrm{mM})$ to elicit CGRP release. CGRP concentrations were determined from $200 \mu \mathrm{L}$ samples of organ fluid of the preparations by means of radioimmunoassay methods developed in our laboratories as described [52,53]. CGRP concentrations were measured also from the media of non-stimulated samples in the presence of resolvins to determine their effect on the baseline peptide release. The trachea samples were weighed and CGRP release was calculated as $\mathrm{fmol} / \mathrm{mg}$ wet tissue. The absolute peptide outflow in response to the chemical stimulations was calculated by adding CGRP release measured in the stimulated and post-stimulated fractions after subtracting the basal release measured in the pre-stimulated $8 \mathrm{~min}$ fraction. In each group, 6 experiments were performed per group (12 tracheae per group; 2 tracheae in each organ bath chamber).

\subsection{Radioactive ${ }^{45} \mathrm{Ca}$-Uptake Experiments in CHO Cells Expressing Cloned TRPV1 or TRPA1 Receptors}

CHO cells stably expressing the human TRPV1 or rat TRPA1 receptor were plated into the medium onto Microwell minitrays (Sigma Inc., Marlborough, MA, USA) in $15 \mu \mathrm{L}$ cell culture, similarly as described earlier for HT1080 cells [57]. The following day, the cells were washed 5 times with calcium-free Hank's solution ( $\mathrm{pH} 7.4$ ), then, incubated in $15 \mu \mathrm{L}$ of the same buffer containing the desired amount of RvD1 and RvD2 (1, 5, and $10 \mathrm{nM})$ on $37^{\circ} \mathrm{C}$ for $60 \mathrm{~min}$. After washing with Hank's solution, the cells were incubated in $10 \mu \mathrm{L}$ of the same buffer containing $100 \mathrm{nM}$ CAPS or $100 \mu \mathrm{M}$ AITC and $200 \mu \mathrm{Ci} / \mathrm{mL}^{45} \mathrm{Ca}$ isotope $(1.3 \mathrm{Ci} / \mathrm{mM}$, Amersham) for $2 \mathrm{~min}$ at room temperature. After washing 5 times with ECS, the residual buffer was evaporated. The $n$, the retained isotope was collected in $15 \mu \mathrm{L} 0.1 \%$ sodium dodecyl sulphate and the radioactivity was measured in $2 \mathrm{~mL}$ scintillation liquid in a Packard Tri-Carb 2800 TR scintillation counter.

\subsection{Fluorescence Spectroscopy to Determine Membrane Polarity Related to Lipid Raft Integrity}

$\mathrm{CHO}$ cells were incubated with Laurdan in $40 \mu \mathrm{M}$ final concentration for $40 \mathrm{~min}$ at $37^{\circ} \mathrm{C}$ in a humidified atmosphere with $5 \% \mathrm{CO}_{2}$. Laurdan is a membrane probe that is sensitive to the polarity of the membrane [40,58]. RvD1 and RvD2 in $100 \mathrm{nM}$ were diluted with ECS and added to the cell wells for $45 \mathrm{~min}$ at $37^{\circ} \mathrm{C}$ before Laurdan administration, respectively. Cells were then washed 3 times with PBS and scraped from the plates into $1 \mathrm{~mL}$ PBS. Fluorescence excitation and emission spectra, excitation-emission matrices, and anisotropy spectra were measured by a HORIBA Jobin-Yvon Nanolog FL3-2iHR spectrofluorometer equipped with a $450 \mathrm{~W}$ xenon lamp. Samples were measured in a $4 \mathrm{mM}$ path length quartz cuvette (Hellma 104F-QS) and kept at a constant $20^{\circ} \mathrm{C}$ using a Thermo Scientific circulating bath AC200-A25. Excitation-emission matrices consisting of a series of emission spectra recorded at different excitation wavelengths were measured to determine spectral changes. An excitation-emission matrix has one axis for the emission wavelengths, while the other includes the 
excitation wavelengths. At the intersection points, fluorescence intensity can be read as the value of the third axis. Steady-state emission anisotropy was measured in "L-format" arrangements to study the molecular mobility. Excitation was vertically polarized, while anisotropy was calculated from consecutively measured vertical and horizontally polarized emission intensities. Anisotropy $<r>$ is defined as

$$
<r>=\frac{I_{V V}-G * I_{V H}}{I_{V V}+2 * G * I_{V H}}
$$

where $G$ is the spectrofluorometer's sensitivity factor given by:

$$
G=\frac{I_{H V}}{I_{H H}}
$$

where $I_{H V}$ and $I_{H H}$ are measured using horizontally polarized excitation and vertically and horizontally polarized emission, respectively. The $G$ value was automatically recalculated at each wavelength point of the anisotropy measurements.

\subsection{Drugs and Chemicals}

CAPS and AITC (Sigma, St. Louis, MO, USA) were dissolved in dimethyl sulfoxide (DMSO) to obtain a $10 \mathrm{mM}$ stock solution. Further dilutions were made with ECS or Krebs solution to reach final concentrations of 330 and $100 \mathrm{nM}$ in the case of CAPS and 200 or $100 \mu \mathrm{M}$ in the case of AITC, respectively. RvD1 an RvD2 were purchased from Cayman Chemical in an ethanolic solution. Laurdan was purchased from Sigma and dissolved in (DMSO) to obtain a $10 \mathrm{mM}$ stock solution. PTX was purchased from Sigma and dissolved in ECS. DMEM, horse serum, fetal bovine albumin, and newborn calf serum were purchased from Gibco (Grand Island, NY, USA). Collagenase, deoxyribonuclease I, poly-D-lysine, and NGF were purchased from Sigma.

\subsection{Statistical Analysis}

The Kolmogorov-Smirnov normality test showed normal distribution for all data sets; we performed the analysis of variance (ANOVA) for statistical analysis. Data reported in this paper are the means \pm SEM of six to eight independent experiments in the case of $\mathrm{Ca}^{2+}$-influx measurement in cultured TG neurons and measurement of CGRP release, and nine independent experiments in the case of ${ }^{45} \mathrm{Ca}$-uptake experiments in $\mathrm{CHO}$ cells. In the CGRP release measurements in each group six experiments were performed per group (12 tracheae per group; 2 tracheae in each organ bath chamber). Fluorescence spectroscopy measurements were performed with four samples per group. Statistical analysis was performed by one-way ANOVA with Dunnett's post hoc test; in all cases $p<0.05$ was considered statistically significant.

Author Contributions: Conceptualization É.S. (Éva Szőke) and J.S.; methodology, M.P., Á.H., T.B.-S., É.S. (Éva Sághy), J.E., G.M., K.P., A.K., M.K.; formal analysis, M.P., Á.H.; investigation, M.P., Á.H., T.B.-S., É.S. (Éva Sághy), J.E., G.M., É.S. (Éva Szőke), K.P., A.K., M.K.; resources, Z.H., É.S. (Éva Szőke); writing—original draft preparation, A.H., M.P.; writing—review and editing, É.S. (Éva Szőke), Z.H.; visualization, Á.H.; supervision, É.S. (Éva Sző́ke), Z.H.; project administration, Á.H., M.P.; funding acquisition, Z.H., É.S. (Éva Sző́ke). All authors have read and agreed to the published version of the manuscript.

Funding: This work was supported by the National Brain Research Program 2017-1.2.1-NKP-2017-00002 (NAP-2; Chronic Pain Research Group). We acknowledge the grant of the Hungarian Government (GINOP-2.3.2-15-2016-00050, EFOP-3.6.2-16-2017-00006 and EFOP-3.6.2-16-2017-00008). É. Szőke A. Kecskés and É. Sághy were supported by the János Bolyai Research Scholarship of the Hungarian Academy of Sciences. The University of Pécs is acknowledged for a support by the 17886-4/23018/FEKUTSTRAT excellence grant. M. Payrits was supported by the New National Excellence Program of the ministry of Human Capacities ÚNKP-18-4. É. Szőke and É. Sághy were supported by the New National Excellence Program of the ministry of Human Capacities ÚNKP-18-4 and New National Excellence Program of the ministry for Innovation and Technology ÚNKP-19-4 grant. 
Acknowledgments: The authors thank Cecília Disztl for expert technical assistance. The fluorescence spectroscopy measurements were performed at the Fluorescence Spectroscopy Laboratory of High Resolution Imaging core facility of the János Szentágothai Research Centre and Centre for Neuroscience.

Conflicts of Interest: The authors declare no conflict of interest.

\section{Abbreviations}

$\begin{array}{ll}{\left[\mathrm{Ca}^{2+}\right]_{i}} & \text { intracellular free calcium concentration } \\ \text { AITC } & \text { allyl isothiocyanate } \\ \text { CAPS } & \text { capsaicin } \\ \text { CHO } & \text { Chinese hamster ovary } \\ \text { CGRP } & \text { calcitonin gene-related peptide } \\ \text { DMEM } & \text { Dulbecco's Modified Eagle Medium } \\ \text { DMSO } & \text { dimethyl sulfoxide } \\ \text { DRG } & \text { dorsal root ganglion } \\ \text { ECS } & \text { extracellular solution } \\ \text { fura-2-AM } & \text { fura-2-acetoxymethyl ester } \\ \text { GPR } & \text { G protein-coupled receptor } \\ \text { Laurdan } & \text { 6-dodecanoyl-N,N-dimethyl-naphthylamine } \\ \text { NGF } & \text { nerve growth factor } \\ \text { PBS } & \text { phosphate-buffered saline } \\ \text { PTX } & \text { Pertussis toxin } \\ \text { RvD1 } & \text { Resolvin D1 } \\ \text { RvD2 } & \text { Resolvin D2 } \\ \text { SM } & \text { sphingomyelin } \\ \text { TG } & \text { trigeminal ganglion } \\ \text { TRP } & \text { Transient Receptor Potential } \\ \text { TRPA1 } & \text { Transient Receptor Potential Ankyrin 1 } \\ \text { TRPV1 } & \text { Transient Receptor Potential Vanilloid 1 } \\ & \end{array}$

\section{References}

1. Caterina, M.J.; Park, U. Chapter 4 TRPV1: A Polymodal Sensor in the Nociceptor Terminal. In Current Topics in Membranes; Elsevier: Amsterdam, The Netherlands, 2006; Volume 57, pp. 113-150, ISBN 978-0-12-153357-1.

2. Holzer, P. The pharmacological challenge to tame the transient receptor potential vanilloid-1 (TRPV1) nocisensor. Br. J. Pharmacol. 2008, 155, 1145-1162. [CrossRef]

3. Szolcsányi, J. Hot target on nociceptors: Perspectives, caveats and unique features. Br. J. Pharmacol. 2008, 155, 1142-1144. [CrossRef] [PubMed]

4. Moran, M.M.; Szallasi, A. Targeting nociceptive transient receptor potential channels to treat chronic pain: Current state of the field: Nociceptive TRP channels. Br. J. Pharmacol. 2018, 175, 2185-2203. [CrossRef] [PubMed]

5. Raisinghani, M.; Pabbidi, R.M.; Premkumar, L.S. Activation of transient receptor potential vanilloid 1 (TRPV1) by resiniferatoxin: Activation of TRPV1 by resiniferatoxin. J. Physiol. 2005, 567, 771-786. [CrossRef] [PubMed]

6. Smart, D.; Gunthorpe, M.J.; Jerman, J.C.; Nasir, S.; Gray, J.; Muir, A.I.; Chambers, J.K.; Randall, A.D.; Davis, J.B. The endogenous lipid anandamide is a full agonist at the human vanilloid receptor (hVR1). Br. J. Pharmacol. 2000, 129, 227-230. [CrossRef] [PubMed]

7. Hwang, S.W.; Cho, H.; Kwak, J.; Lee, S.-Y.; Kang, C.-J.; Jung, J.; Cho, S.; min, K.H.; Suh, Y.-G.; Kim, D.; et al. Direct activation of capsaicin receptors by products of lipoxygenases: Endogenous capsaicin-like substances. Proc. Natl. Acad. Sci. USA 2000, 97, 6155-6160. [CrossRef] [PubMed]

8. Bianchi, B.R.; Lee, C.-H.; Jarvis, M.F.; El Kouhen, R.; Moreland, R.B.; Faltynek, C.R.; Puttfarcken, P.S. Modulation of human TRPV1 receptor activity by extracellular protons and host cell expression system. Eur. J. Pharmacol. 2006, 537, 20-30. [CrossRef] 
9. Welch, J.M.; Simon, S.A.; Reinhart, P.H. The activation mechanism of rat vanilloid receptor 1 by capsaicin involves the pore domain and differs from the activation by either acid or heat. Proc. Natl. Acad. Sci. USA 2000, 97, 13889-13894. [CrossRef]

10. Myers, B.R.; Bohlen, C.J.; Julius, D. A Yeast Genetic Screen Reveals a Critical Role for the Pore Helix Domain in TRP Channel Gating. Neuron 2008, 58, 362-373. [CrossRef]

11. Macpherson, L.J.; Dubin, A.E.; Evans, M.J.; Marr, F.; Schultz, P.G.; Cravatt, B.F.; Patapoutian, A. Noxious compounds activate TRPA1 ion channels through covalent modification of cysteines. Nature 2007, 445, 541-545. [CrossRef]

12. McNamara, C.R.; Mandel-Brehm, J.; Bautista, D.M.; Siemens, J.; Deranian, K.L.; Zhao, M.; Hayward, N.J.; Chong, J.A.; Julius, D.; Moran, M.M.; et al. TRPA1 mediates formalin-induced pain. Proc. Natl. Acad. Sci. USA 2007, 104, 13525-13530. [CrossRef]

13. Eberhardt, M.J.; Filipovic, M.R.; Leffler, A.; de la Roche, J.; Kistner, K.; Fischer, M.J.; Fleming, T.; Zimmermann, K.; Ivanovic-Burmazovic, I.; Nawroth, P.P.; et al. Methylglyoxal Activates Nociceptors through Transient Receptor Potential Channel A1 (TRPA1): A Possible Mechanism of Metabolic Neuropathies. J. Biol. Chem. 2012, 287, 28291-28306. [CrossRef] [PubMed]

14. Story, G.M.; Peier, A.M.; Reeve, A.J.; Eid, S.R.; Mosbacher, J.; Hricik, T.R.; Earley, T.J.; Hergarden, A.C.; Andersson, D.A.; Hwang, S.W.; et al. ANKTM1, a TRP-like Channel Expressed in Nociceptive Neurons, is Activated by Cold Temperatures. Cell 2003, 112, 819-829. [CrossRef]

15. Corey, D.P.; García-Añoveros, J.; Holt, J.R.; Kwan, K.Y.; Lin, S.-Y.; Vollrath, M.A.; Amalfitano, A.; Cheung, E.L.-M.; Derfler, B.H.; Duggan, A.; et al. TRPA1 is a candidate for the mechanosensitive transduction channel of vertebrate hair cells. Nature 2004, 432, 723-730. [CrossRef]

16. Vilceanu, D.; Stucky, C.L. TRPA1 Mediates Mechanical Currents in the Plasma Membrane of Mouse Sensory Neurons. PLoS ONE 2010, 5, e12177. [CrossRef] [PubMed]

17. Helyes, Z.; Németh, J.; Thán, M.; Bölcskei, K.; Pintér, E.; Szolcsányi, J. Inhibitory effect of anandamide on resiniferatoxin-induced sensory neuropeptide release in vivo and neuropathic hyperalgesia in the rat. Life Sci. 2003, 73, 2345-2353. [CrossRef]

18. Helyes, Z.; Pinter, E.; Sandor, K.; Elekes, K.; Banvolgyi, A.; Keszthelyi, D.; Szoke, E.; Toth, D.M.; Sandor, Z.; Kereskai, L.; et al. Impaired defense mechanism against inflammation, hyperalgesia, and airway hyperreactivity in somatostatin 4 receptor gene-deleted mice. Proc. Natl. Acad. Sci. USA 2009, 106, 13088-13093. [CrossRef]

19. Szolcsányi, J. Forty years in capsaicin research for sensory pharmacology and physiology. Neuropeptides 2004, 38, 377-384. [CrossRef]

20. Nassenstein, C.; Krasteva-Christ, G.; Renz, H. New aspects of neuroinflammation and neuroimmune crosstalk in the airways. J. Allergy Clin. Immunol. 2018, 142, 1415-1422. [CrossRef]

21. Chen, Y.; Mu, J.; Zhu, M.; Mukherjee, A.; Zhang, H. Transient Receptor Potential Channels and Inflammatory Bowel Disease. Front. Immunol. 2020, 11, 180. [CrossRef]

22. Abdolmaleki, F.; Kovanen, P.T.; Mardani, R.; Gheibi-hayat, S.M.; Bo, S.; Sahebkar, A. Resolvins: Emerging Players in Autoimmune and Inflammatory Diseases. Clin. Rev. Allergy Immunol. 2020, 58, 82-91. [CrossRef] [PubMed]

23. Szolcsányi, J.; Sándor, Z. Multisteric TRPV1 nocisensor: A target for analgesics. Trends Pharmacol. Sci. 2012, 33, 646-655. [CrossRef]

24. Szallasi, A.; Cortright, D.N.; Blum, C.A.; Eid, S.R. The vanilloid receptor TRPV1: 10 years from channel cloning to antagonist proof-of-concept. Nat. Rev. Drug Discov. 2007, 6, 357-372. [CrossRef]

25. Gavva, N.R. Body-temperature maintenance as the predominant function of the vanilloid receptor TRPV1. Trends Pharmacol. Sci. 2008, 29, 550-557. [CrossRef]

26. Gunthorpe, M.J.; Chizh, B.A. Clinical development of TRPV1 antagonists: Targeting a pivotal point in the pain pathway. Drug Discov. Today 2009, 14, 56-67. [CrossRef] [PubMed]

27. Preti, D.; Saponaro, G.; Szallasi, A. Transient receptor potential ankyrin 1 (TRPA1) antagonists. Pharma. Pat. Anal. 2015, 4, 75-94. [CrossRef]

28. Garami, A.; Shimansky, Y.P.; Rumbus, Z.; Vizin, R.C.L.; Farkas, N.; Hegyi, J.; Szakacs, Z.; Solymar, M.; Csenkey, A.; Chiche, D.A.; et al. Hyperthermia induced by transient receptor potential vanilloid-1 (TRPV1) antagonists in human clinical trials: Insights from mathematical modeling and meta-analysis. Pharmacol. Ther. 2020, 208, 107474. [CrossRef] [PubMed] 
29. Sántha, P.; Dobos, I.; Kis, G.; Jancsó, G. Role of Gangliosides in Peripheral Pain Mechanisms. Int. J. Mol. Sci. 2020, 21, 1005. [CrossRef] [PubMed]

30. Liu, M.; Huang, W.; Wu, D.; Priestley, J.V. TRPV1, but not P2X 3 , requires cholesterol for its function and membrane expression in rat nociceptors. Euro. J. Neurosci. 2006, 24, 1-6. [CrossRef] [PubMed]

31. Sághy, É.; Szőke, É.; Payrits, M.; Helyes, Z.; Börzsei, R.; Erostyák, J.; Jánosi, T.Z.; Sétáló, G., Jr.; Szolcsányi, J. Evidence for the role of lipid rafts and sphingomyelin in $\mathrm{Ca}^{2+}$-gating of Transient Receptor Potential channels in trigeminal sensory neurons and peripheral nerve terminals. Pharmacol. Res. 2015, 100, 101-116. [CrossRef]

32. Sághy, É.; Payrits, M.; Bíró-Sütő, T.; Skoda-Földes, R.; Szánti-Pintér, E.; Erostyák, J.; Makkai, G.; Sétáló, G.; Kollár, L.; Kőszegi, T.; et al. Carboxamido steroids inhibit the opening properties of transient receptor potential ion channels by lipid raft modulation. J. Lipid Res. 2018, 59, 1851-1863. [CrossRef] [PubMed]

33. Startek, J.B.; Talavera, K. Lipid Raft Destabilization Impairs Mouse TRPA1 Responses to Cold and Bacterial Lipopolysaccharides. Int. J. Mol. Sci. 2020, 21, 3826. [CrossRef] [PubMed]

34. Startek, J.B.; Boonen, B.; López-Requena, A.; Talavera, A.; Alpizar, Y.A.; Ghosh, D.; Van Ranst, N.; Nilius, B.; Voets, T.; Talavera, K. Mouse TRPA1 function and membrane localization are modulated by direct interactions with cholesterol. Elife 2019, 8. [CrossRef]

35. Startek, J.; Boonen, B.; Talavera, K.; Meseguer, V. TRP Channels as Sensors of Chemically-Induced Changes in Cell Membrane Mechanical Properties. Int. J. Mol. Sci. 2019, 20, 371. [CrossRef] [PubMed]

36. Ciardo, M.G.; Ferrer-Montiel, A. Lipids as central modulators of sensory TRP channels. Biochim. Biophys. Acta Biomembr. 2017, 1859, 1615-1628. [CrossRef]

37. Kobayashi, T.; Takahashi, M.; Nagatsuka, Y.; Hirabayashi, Y. Lipid Rafts: New Tools and a New Component. Biol. Pharm. Bull. 2006, 29, 1526-1531. [CrossRef]

38. Kiyokawa, E.; Baba, T.; Otsuka, N.; Makino, A.; Ohno, S.; Kobayashi, T. Spatial and Functional Heterogeneity of Sphingolipid-rich Membrane Domains. J. Biol. Chem. 2005, 280, 24072-24084. [CrossRef]

39. Harris, F.M.; Best, K.B.; Bell, J.D. Use of laurdan fluorescence intensity and polarization to distinguish between changes in membrane fluidity and phospholipid order. Biochim. Biophys. Acta Biomembr. 2002, 1565, 123-128. [CrossRef]

40. Gaus, K.; Gratton, E.; Kable, E.P.W.; Jones, A.S.; Gelissen, I.; Kritharides, L.; Jessup, W. Visualizing lipid structure and raft domains in living cells with two-photon microscopy. Proc. Natl. Acad. Sci. USA 2003, 100, 15554-15559. [CrossRef]

41. Serhan, C.N.; Hong, S.; Gronert, K.; Colgan, S.P.; Devchand, P.R.; Mirick, G.; Moussignac, R.-L. Resolvins. J. Exp. Med. 2002, 196, 1025-1037. [CrossRef]

42. Serhan, C.N.; Chiang, N. Endogenous pro-resolving and anti-inflammatory lipid mediators: A new pharmacologic genus: Novel agonists of resolution. Br. J. Pharmacol. 2009, 153, S200-S215. [CrossRef] [PubMed]

43. Bang, S.; Yoo, S.; Yang, T.; Cho, H.; Kim, Y.; Hwang, S. Resolvin D1 attenuates activation of sensory transient receptor potential channels leading to multiple anti-nociception: Resolvin D1 inhibits sensory TRPs. Br. J. Pharmacol. 2010, 161, 707-720. [CrossRef] [PubMed]

44. Xu, Z.-Z.; Zhang, L.; Liu, T.; Park, J.Y.; Berta, T.; Yang, R.; Serhan, C.N.; Ji, R.-R. Resolvins RvE1 and RvD1 attenuate inflammatory pain via central and peripheral actions. Nat. Med. 2010, 16, 592-597. [CrossRef] [PubMed]

45. Huang, L.; Wang, C.-F.; Serhan, C.N.; Strichartz, G. Enduring prevention and transient reduction of postoperative pain by intrathecal resolvin D1. Pain 2011, 152, 557-565. [CrossRef] [PubMed]

46. Spite, M.; Norling, L.V.; Summers, L.; Yang, R.; Cooper, D.; Petasis, N.A.; Flower, R.J.; Perretti, M.; Serhan, C.N. Resolvin D2 is a potent regulator of leukocytes and controls microbial sepsis. Nature 2009, 461, 1287-1291. [CrossRef]

47. Park, C.-K.; Xu, Z.-Z.; Liu, T.; Lu, N.; Serhan, C.N.; Ji, R.-R. Resolvin D2 Is a Potent Endogenous Inhibitor for Transient Receptor Potential Subtype V1/A1, Inflammatory Pain, and Spinal Cord Synaptic Plasticity in Mice: Distinct Roles of Resolvin D1, D2, and E1. J. Neurosci. 2011, 31, 18433-18438. [CrossRef]

48. Chiang, N.; Dalli, J.; Colas, R.A.; Serhan, C.N. Identification of resolvin D2 receptor mediating resolution of infections and organ protection. J. Exp. Med. 2015, 212, 1203-1217. [CrossRef]

49. Krishnamoorthy, S.; Recchiuti, A.; Chiang, N.; Yacoubian, S.; Lee, C.-H.; Yang, R.; Petasis, N.A.; Serhan, C.N. Resolvin D1 binds human phagocytes with evidence for proresolving receptors. Proc. Natl. Acad. Sci. USA 2010, 107, 1660-1665. [CrossRef] 
50. Chiang, N.; Barnaeva, E.; Hu, X.; Marugan, J.; Southall, N.; Ferrer, M.; Serhan, C.N. Identification of Chemotype Agonists for Human Resolvin D1 Receptor DRV1 with Pro-Resolving Functions. Cell Chem. Biol. 2019, 26, 244-254.e4. [CrossRef]

51. Jo, Y.Y.; Lee, J.Y.; Park, C.-K. Resolvin E1 Inhibits Substance P-Induced Potentiation of TRPV1 in Primary Sensory Neurons. Med. Inflamm. 2016, 2016, 1-9. [CrossRef]

52. Helyes, Z.; Németh, J.; Pintér, E.; Szolcsányi, J. Inhibition by nociceptin of neurogenic inflammation and the release of SP and CGRP from sensory nerve terminals. Br. J. Pharmacol. 1997, 121, 613-615. [CrossRef] [PubMed]

53. Németh, J.; Helyes, Z.; Görcs, T.; Gardi, J.; Pintér, E.; Szolcsányi, J. Development of somatostatin radioimmunoassay for the measurement of plasma and tissue contents of hormone. Acta Physiol. Hung. 1996, 84, 313-315. [PubMed]

54. Bang, S.; Yoo, S.; Yang, T.; Cho, H.; Hwang, S. 17(R)-resolvin D1 specifically inhibits transient receptor potential ion channel vanilloid 3 leading to peripheral antinociception: 17R-RvD1 is a specific inhibitor of TRPV3. Br. J. Pharmacol. 2012, 165, 683-692. [CrossRef] [PubMed]

55. Quan-Xin, F.; Fan, F.; Xiang-Ying, F.; Shu-Jun, L.; Shi-Qi, W.; Zhao-Xu, L.; Xu-Jie, Z.; Qing-Chuan, Z.; Wei, W. Resolvin D1 reverses chronic pancreatitis-induced mechanical allodynia, phosphorylation of nMDA receptors, and cytokines expression in the thoracic spinal dorsal horn. BMC Gastroenterol. 2012, 12. [CrossRef] [PubMed]

56. Szőke, É.; Balla, Z.; Csernoch, L.; Czéh, G.; Szolcsányi, J. Interacting effects of capsaicin and anandamide on intracellular calcium in sensory neurones. NeuroReport 2000, 11, 1949-1952. [CrossRef] [PubMed]

57. Sándor, Z.; Varga, A.; Horváth, P.; Nagy, B.; Szolcsányi, J. Construction of a stable cell line uniformly expressing the rat TRPV1 receptor. Cell. Mol. Biol. Lett. 2005, 10, 499-514.

58. Golfetto, O.; Hinde, E.; Gratton, E. Laurdan Fluorescence Lifetime Discriminates Cholesterol Content from Changes in Fluidity in Living Cell Membranes. Biophys. J. 2013, 104, 1238-1247. [CrossRef]

(C) 2020 by the authors. Licensee MDPI, Basel, Switzerland. This article is an open access article distributed under the terms and conditions of the Creative Commons Attribution (CC BY) license (http://creativecommons.org/licenses/by/4.0/). 